\title{
Drones as sons of drones in Apis mellifera
}

\author{
N. Koeniger, C. Hemmling and T. Yoshida \\ Johann Wolfgang Goethe Universität, Fachbereich Biologie, Institut für Bienenkunde (Polytechnis- \\ che Gesellschaft), Frankfurt a. M., Karl-von-Frisch-Weg 2, D 6370 Oberursel, FRG
}

(received 16 May 1989, accepted 8 August 1989)

Summary - Homozygous cordovan queens (Apis mellifera carnica) were inseminated by dark (+) and by brown (cd) drones (A. m. carnica) and kept in colonies of dark Carniolan workers Sealed brood out of these colonies was transferred into an incubator until emergence. Among the offspring of 3 colonies, some dark drones were found. In a second experiment, the same queers were introduced into colonies consisting entirely of yellow Italian workers (A. m. ligustica). Again dark drones were found among the progeny. Therefore, we conclude that these drones originated from the nucleus of a sperm. This mechanism of drone development in Apis mellifera is reported for the first time.

Apis mellifera - genetics - drone development - sex determination

\section{INTRODUCTION}

In the honey bee (Apis mellifera), drones develop from unfertilized eggs (Dzierzon, 1845). In the case of homozygous sex alleles, diploid drones develop from fertilized eggs (Woyke, 1963). In this paper a third mechanism of drone development is reported.

\section{MATERIAL AND METHODS}

Cordovan is a recessive mutation which results in brown body pigment (Mackensen, 1951). Sixty-one Carniolan queens (A. m. carnica), homozygous for cordovan (cd/cd) were allowed to mate naturally on a congregation area in Austria. The drone population (A. $\mathrm{m}$. carnica) was composed of approximately equal proportions of dark $(+)$ and cordovan (cd) drones (Koeniger et al, 1989). After mating the queens were kept in small hives, each containing 4 small frames and about 2000 dark worker bees of $A$. m. carnica. Combs containing sealed brood from each queen were transferred into an incubator and kept in separate boxes at $34.5^{\circ} \mathrm{C}$ and 60 to $70 \% \mathrm{rol}$ ative humidity. The emerged bees were re moved and classified daily.

In a second experiment, 3 of the above queens were introduced into new colonies consisting of 2000 yellow worker bees of $A$ $m$. ligustica. Again brood combs were brought into an incubator and the emerging bees were classified from each queen.

\section{RESULTS AND DISCUSSION}

A small number of dark drones and several gynandromorphs were found among 
Table l. Offspring of $3(\mathrm{~cd} / \mathrm{cd} \times \mathrm{cd},+)$ queens kept in colonies of dark Carniolan workers (A. m. carnica) (1).

\begin{tabular}{cccccc}
\hline \multirow{2}{*}{ Queen } & Workers & \multicolumn{4}{c}{ Number of drones } \\
\cline { 3 - 6 } No. & \% dark & Sum & \multicolumn{4}{c}{$c d$} & + & Gynandrom \\
\hline & & & & 11 & 27 \\
29 & 95 & 40 & 2 & 1 & 14 \\
231 & 68 & 19 & 4 & 27 & 4 \\
\hline
\end{tabular}

$\%$ dark = percentage of dark $(\mathrm{cd} /+)$ worker offspring; sum = sum of all drones which were found;

$\mathrm{cd}=$ cordovan drones (uniform leather brown body pigment);

$+=$ dark Carniolan drones (uniform dark body pigment);

gynandrom = gynandromorphs which had a mosaic of brown (cd) and dark tissue.

the offspring of 3 of the 61 queens. These results are presented in Table I. First, we suspected that the dark $(+)$ drones originated from the dark Carniolan workers of the colony, although inspection of the eggs showed no indications of worker's eggs (position at the edge of the cell ground or at wall of the cell). However, some drones observed in the second experiment again had the dark body pigment of $A$. $m$. carnica (Table II). Because only yellow A. m. ligustica workers were found in a thorough inspection of the colonies, the drones were not produced by the worker bees. So, we conclude that the drones were progeny of the queens.

Since all the queens were homozygous for cordovan, unfertilized eggs would develop into cordovan drones. We found cordovan drones in queens No. 29 and No. 216. The gynandromorphs had parts of cordovan and dark coloured tissue. In some of these creatures, the dark parts (eye and legs) were of female shape and the brown (cd) parts showed male characters. Thus, they were gynandromorphs with matroclinous male tissue, as de-

Table II. Drones produced by 3 (cd /cd $x \mathrm{~cd},+$ ) queens in colonies of yellow Italian workers (A. $m$. ligustica) (1).

\begin{tabular}{crrrr}
\hline \multirow{2}{*}{ Queen Number } & \multirow{2}{*}{ Sum } & \multicolumn{3}{c}{ Number of drones } \\
\cline { 3 - 5 } & & cd & + & Gynandrom \\
\cline { 3 - 5 } 29 & 11 & 6 & 2 & 3 \\
216 & 22 & 5 & 2 & 15 \\
231 & 3 & 0 & 2 & 1 \\
& & & & \\
\hline
\end{tabular}

(1) Abbreviations as in Table I. 
scribed by Mackensen (1951), and Drescher and Rothenbuhler (1963).

The queens were partially inseminated by dark (+) drones and they produced mainly dark workers (Table 1). In the case of homozygous sex alleles, diploid drones would occur. The natural mating of the queens with dark, unrelated drones and the cannibalism of diploid drone larvae by nurse bees (Woyke, 1986) seem to exclude this possibility. So, if the dark drones were haploid, they originated from the nucleus of a sperm. These "paternal" drones as well as the matroclinous gynandromorphs might be linked to a factor in the egg's plasma which interfered with the normal course of fertilisation and cleavage.

Further research on these remarkable queens is in preparation.

Résumé - Les mâles, fils de mâles chez Apis mellifica. Depuis la découverte de la parthénogénèse chez l'abeille par Dzierzon en 1845 , on sait que les mâles proviennent d'œufs non fécondés. Ce n'est que beaucoup plus tard que J. Woyke montra que les mâles pouvaient provenir d'œufs fécondés, donc diploïdes. De tels mâles diploïdes proviennent de l'homozygotie au locus sexuel et se rencontrent relativement souvent lorsqu'il y a accouplement d'insectes proches parents. Mais dans la ruche, les larves de mâles diploïdes sont immédiatement reconnues par les nourrices dès l'éclosion de l'œuf et mangées, de sorte qu'on ne peut obtenir un tel élevage qu'en laboratoire. On décrit ici une troisième voie de production des mâles.

On a fait s'accoupler naturellement 100 reines cordovan homozygotes $(\mathrm{cd} / \mathrm{cd})$ de la race Apis m. carnica sur un lieu de rassemblement de mâles, dont la population était composée pour moitié de mâles foncés $(+)$ et pour moitié de mâles cordovan (cd). Le couvain a été placé en étuve jusqu'à l'émergence et les jeunes abeilles écloses classées. Sur les rayons de 3 colonies on a trouvé, à côté d'ouvrières normales, des mâles foncés et, en outre, quelques gynandromorphes (formes intermédiaires entre ouvrière et mâle) ( $\mathrm{Ta}$ bleau 1). Afin d'exclure la possibilité que les mâles foncés soient produits par les ouvrières, on a introduit les reines dans de nouvelles ruches composées d'abeilles jaunes ( $\boldsymbol{A}$. $m$. ligustica). Et à nouveau on a trouvé des mâles foncés (Tableau II). Le fait que les reines se soient accouplées librement avec des mâles non apparentés et que les mâles foncés aient été élevés naturellement dans la colonie rend impro bable la production de mâles diploïdes. Dans la mesure où il s'agit donc d'insectes haploïdes, les mâles ne peuvent provenir que d'un noyau de sperme. C'est la première fois que l'on relate ce mode de production des mâles.

Zusammenfassung - Drohnen als Söhne von Drohnen bei Apis mellifera. Seit der Entdeckung der Parthenogenese bei der Honigbiene durch J. Dzierzon 1845 ist die Entstehung der Drohnen aus unbefruchteten Eiern als Regelfall bekannt. Erst sehr viel später wurde von J. Woyke eine Drohnenentstehung aus befruchteten, also diploiden Eiern nachgewiesen. Solche diploiden Drohnen entstehen durch Homozygotie am Sexlocus und treten relativ häufig bei Verpaarung von nahverwandten Tieren auf. Die diploiden Drohnenlarven werden aber im Volk sofort nach dem Schlupf aus dem $E i$ von den Ammenbienen erkannt und gefressen, so daß eine Aufzucht solcher Tiere nur unter Laborabedingungen gelingt.

Bei unseren Untersuchungen wurden 100 homozygote cordovan (cd/cd) Königinnen der Rasse A. m. carnica auf ei- 
nen Sammelplatz zur Paarung gebracht, dessen Drohnen etwa zur einen Hälfte aus dunklen $(+)$ Drohnen und zur anderen Hälfte aus braunen (cd) Carnicadrohnen bestand. Nach der natürlichen Paarung wurden die Königinnen in Völkern mit dunklen Carnicabienen gehalten. Die Brut wurde zum Schlupf in einen Brutschrank gebracht und klassifiziert. Auf Waben von drei Völkern wurden neben normalen $\mathrm{Ar}$ beiterinnen auch dunkle Drohnen gefunden, daneben traten auch einige Gynandromorphe (Mischformen zwischen Arbeiterin und Drohn) auf (Tab. I). Um auszuschließen, daß die dunklen Drohnen von Arbeiterinnen erzeugt waren, wurden die Königinnen in neue Völker eingeweiselt, die aus gelben Bienen der Rasse A. $\mathrm{m}$. ligustica bestanden. Wiederum traten dunkle Drohnen auf (Tab. II). Die freie Paarung der Königinnen mit unverwandten Drohnen und die natürliche Aufzucht der dunklen Drohnen im Volk machen eine Entstehung von diploiden Drohnen unwahrscheinlich. Sofern es sich also um haploide Tiere handelt, kann die Entstehung der Drohnen nur aus einem Sper- makern erfolgt sein. Über diese Art der Entstehung von Drohnen wird zum ersten Mal berichtet.

\section{REFERENCES}

Drescher W. \& Rothenbuhler W.C. (1963) Gynandromorph production by egg chilling. $J$. Hered. 54(5), 195-201

Dzierzon J. (1845) Gutachten über die von Herrn Direktor Stöhr im ersten und zweiten Kapitel des General-Gutachtens aufgestellten Fragen. Bienenzeitung 1, 109-113, 119-121

Koeniger G., Koeniger N., Pechhacker H., Ruttner F. \& Berg S. (1989) Assortative mating in a mixed population of European honeybees. Insectes Soc. 36, 129-138

Mackensen O. (1951) Self fertilisation in the honey bee. Glean. Bee Cult. 79, 273-275

Woyke J. (1963) Drone larvae from fertilized eggs of the honeybee. J. Apic. Res. 2(2), 73-75

Woyke J. (1986) Sex determination. In : Bee Genetics and Breeding (Rinderer T., ed.) Academic Press, New York, pp. 91-115 